\title{
Infection with netilmicin resistant Serratia marcescens in a special care baby unit
}

\author{
D A LEWIS, P M HAWKEY, J A WATTS, D C E SPELlER, R J PRIMAVESI, P J FLEMING, \\ T L PITT
}

\begin{abstract}
An outbreak of colonisation and infection with a netilmicin resistant strain of Serratia marcescens occurred in a special care baby unit. $S$ marcescens was isolated from a total of 13 babies; significant infection occurred in five, of whom two died. Epidemiological investigation failed to detect a common source but gastrointestinal colonisation of babies formed a prolonged and possibly important reservoir for infection. Containment proved difficult until the unit was closed to new admissions, and even then spread to a temporary unit ensued.

$O$ Serotyping and bacteriophage typing disclosed a single epidemic strain. This produced an aminoglycoside acetylating enzyme $\left(\mathrm{AAC}\left(6^{\prime}\right)\right)$ conferring resistance to netilmicin and tobramycin and moderate resistance to amikacin. Use of gentamicin resulted in the isolation of serratia with increased resistance to all aminoglycosides, and, similarly, increased resistance to third generation cephalosporins emerged with their use.
\end{abstract}

\section{Introduction}

Serratia marcescens is a well recognised cause of nosocomial infection, and outbreaks in neonatal units have been described. ${ }^{1-4}$ Usually these proved difficult to control unless an environmental point source was identified and eliminated. ${ }^{5}$ The strains of serratia responsible for outbreaks of cross infection have often been resistant to many antibiotics including gentamicin. ${ }^{6}$ ?

After substituting netilmicin for gentamicin as part of "blind" antibiotic treatment of serious infection in our special care baby unit we experienced an outbreak of colonisation and

Department of Microbiology, Bristol Royal Infirmary, Bristol BS2 8HW

D A LEWIS, MRCPATH, senior registrar in medical microbiology

P M HAWKEY, MD, lecturer in medical microbiology

J A WATTS, FIMLS, senior medical laboratory scientific officer

D C E SPELLER, FRCP, FRCPATH, professor of clinical microbiology

Department of Child Health, Bristol Maternity Hospital, Bristol BS2 8EG

R J PRIMAVESI, MRCP, registrar in paediatrics

P J FLEMING, MRCP, consultant paediatrician

Division of Hospital Infection, Central Public Health Laboratory Colindale, London

T L PITT, PHD, senior microbiologist

Correspondence to: Dr D A Lewis. infection of neonates by a netilmicin resistant strain of $S$ marcescens. ${ }^{8}$ This strain was sensitive to gentamicin but showed reduced sensitivity to amikacin.

We describe the outbreak together with our attempts at control of spread and report the results of epidemiological investigation.

\section{The outbreak}

Of 24 babies investigated in the unit over three months, 11 were colonised or infected with $S$ marcescens. The index patient (case 1 ) was born at 26 weeks of gestation with moderately severe respiratory distress syndrome. He developed consolidation and collapse of his right middle lobe after prolonged dependence on the ventilator. In the first month of life he received four short courses of intravenous netilmicin before the isolation of a netilmicin resistant, gentamicin sensitive $S$ marcescens from endotracheal aspirates. At the same time he developed a purulent conjunctivitis, and a strain of serratia was isolated that was sensitive to netilmicin and gentamicin. He was treated with systemic and topical gentamicin with rapid resolution of his eye infection. Table I gives the clinical details of this patient and of the other babies subsequently affected. Severe infections occurred in five babies in the unit, and two of them died. Two babies (cases 12 and 13) became colonised during their stay in a temporary special care baby unit.

Before this outbreak there had been frequent movement of babies within the unit, depending on their requirement for intensive care facilities, which were concentrated in three large rooms. At the beginning of the outbreak attempts were made to contain the infection by curtailing movement of babies and not putting new admissions in rooms containing colonised babies. Spread, however, occurred very rapidly, and within two weeks five out of eight rooms contained colonised babies. This inability to prevent spread and the fulminant infection resulting in death of the second infant (case 11) necessitated closure of the unit to new patients. Babies born subsequently who required special care were nursed in a postnatal ward, which became a temporary special care baby unit, and those needing intensive treatment were transferred to another Bristol hospital.

A strict isolation policy was instituted; the unit was segregated into "infected" and "non-infected" areas, and nursing staff were assigned to one of the two. Careful attention was paid to handwashing, with the use of alcoholic chlorhexidine rub as well as aqueous chlorhexidine.

The antibiotic policy for the unit was changed during the outbreak. Cephalosporins were substituted for penicillin and netilmicin as "blind" treatment. Initially cefotaxime was used, latamoxef being used instead on one occasion, but later ceftazidime was substituted because of the emergence of serratia isolates with increased resistance to cefotaxime and latamoxef.

The unit was closed for a total of seven weeks, at the end of which the five remaining babies were transferred to a vacant ward until discharge and the unit thoroughly cleaned before reopening. 
TABLE I-Clinical features of neonates infected or colonised with $S$ marcescens

\begin{tabular}{|c|c|c|c|c|c|c|}
\hline $\begin{array}{l}\text { Case } \\
\text { No }\end{array}$ & $\begin{array}{c}\text { Gestational } \\
\text { age } \\
\text { (weeks) }\end{array}$ & $\begin{array}{l}\text { No of days on unit } \\
\text { to first serratia } \\
\text { isolation }\end{array}$ & Site of first isolation & $\begin{array}{c}\text { Previous } \\
\text { netilmicin }\end{array}$ & Diagnosis on admission & $\begin{array}{l}\text { Serratia associated } \\
\text { morbidity/mortality }\end{array}$ \\
\hline 1 & 26 & 42 & $\begin{array}{l}\text { Endotracheal aspirate, } \\
\text { conjunctival swab }\end{array}$ & Yes & $\begin{array}{l}\text { Prematurity, small for dates, } \\
\text { respiratory distress syndrome, } \\
\text { jaundice }\end{array}$ & Conjunctivitis, pneumonia \\
\hline 2 & 33 & 7 & Blood & Yes & $\begin{array}{l}\text { Small for dates, prematurity, } \\
\text { jaundice, severe necrotising } \\
\text { enterocolitis }\end{array}$ & $\begin{array}{l}\text { Septicaemia ( } \\
\text { Died }\end{array}$ \\
\hline 3 & 28 & 8 & $\begin{array}{l}\text { Rectum, urine, umbilicus, } \\
\text { nose }\end{array}$ & No & Apnoea of prematurity, jaundice & $\begin{array}{l}\text { Urinary tract infection with } \\
\text { pyuria, bacteraemia }\end{array}$ \\
\hline 4 & 26 & 24 & Urine & Yes & $\begin{array}{l}\text { Severe respiratory distress } \\
\text { syndrome }\end{array}$ & Bacteraemia \\
\hline 5 & 30 & 54 & $\begin{array}{l}\text { Rectum, urine, umbilicus, } \\
\text { nose }\end{array}$ & Yes & $\begin{array}{l}\text { Prematurity, respiratory distress } \\
\text { syndrome }\end{array}$ & None \\
\hline 6 & 33 & $25^{*}$ & Rectum & Yes & $\begin{array}{l}\text { Maternal placenta praevia, } \\
\text { antepartum haemorrhage, gut } \\
\text { perforation }\end{array}$ & None \\
\hline $\begin{array}{l}7 \\
8\end{array}$ & $\begin{array}{l}29 \\
34\end{array}$ & $\begin{array}{r}16 \\
7\end{array}$ & $\begin{array}{l}\text { Rectum, urine, umbilicus } \\
\text { Rectum }\end{array}$ & $\begin{array}{l}\text { Yes } \\
\text { Yes }\end{array}$ & $\begin{array}{l}\text { Pneumonia } \\
\text { Maternal prolonged ruptured } \\
\text { membranes }\end{array}$ & $\begin{array}{l}\text { None } \\
\text { None }\end{array}$ \\
\hline 9 & 42 & 9 & Rectum, urine & Yes & $\begin{array}{l}\text { Oesophageal atresia, tracheo- } \\
\text { oesophageal fistula }\end{array}$ & None \\
\hline 10 & 35 & 8 & Rectum, urine & No & $\begin{array}{l}\text { Prematurity, small for dates, } \\
\text { tachypnoea, patent ductus } \\
\text { arteriosus }\end{array}$ & None \\
\hline 11 & 35 & 5 & Blood, meninges & No & $\begin{array}{l}\text { Maternal antepartum } \\
\text { haemorrhage, respiratory distress } \\
\text { syndrome }\end{array}$ & $\begin{array}{l}\text { Fulminant septicaemia, } \\
\text { meningitis. Died }\end{array}$ \\
\hline $12 \dagger$ & 37 & 23 & Rectum & No & $\begin{array}{l}\text { Duodenal web, malrotation, } \\
\text { ventricular septal defect }\end{array}$ & None \\
\hline $13+$ & 35 & 7 & Rectum & No & Severe talipes equinovarus & None \\
\hline
\end{tabular}

* Transferred from another hospital at nine days.

tIn postnatal ward (temporary special care baby unit).

\section{Investigation of patients, staff, and environment}

Initially twice weekly (and later weekly) swabs from nose, umbilicus, and rectum together with urine specimens were taken from all babies in the unit. After three weeks perineal swabs were collected in place of urine and after closure of the unit screening was extended to babies in the temporary unit. Rectal swabs were also taken on one occasion from babies in all postnatal wards. Specimens were collected throughout the period that the unit was closed and from colonised babies for the duration of their stay in hospital. After discharge samples of faeces were collected from some colonised babies at weekly intervals for the first month, and thereafter monthly in order to ascertain the duration of carriage of serratia. Surveillance continued after the unit was reopened with weekly nose, umbilical, and rectal swabs from all babies.

Many specimens were collected from the environment: incubators, humidifiers, ventilators, sinks, jugs, buckets, medicaments, intravenous fluids and additives, disinfectant solutions, arterial pressure transducers, breast pumps for expressed breast milk, and a blood gas analyser. Air sampling was also performed with a centrifugal air sampler (Biotest Folex).

Staff were screened for carriage of the organism. Nose swabs and forestream specimens of urine were examined and hand swabs obtained by vigorously rubbing saline moistened swabs over the hands, between fingers, and under the nails. On a second occasion, shortly before the unit was reopened, handwashings were obtained from all staff by agitation of each hand in turn in a sterile plastic bag containing about $30 \mathrm{ml} \mathrm{2.5 \%}$ heart infusion broth (Becton Dickinson), the contents of which were then transferred to a sterile screwcapped container.

\section{LABORATORY METHODS}

Nasal, umbilical, and perineal swabs and urine specimens were plated on to (a) $5 \%$ horse blood agar with a $30 \mu \mathrm{g}$ netilmicin disc to detect netilmicin resistant bacteria, and $(b)$ a medium selective for serratia containing deoxyribonucleic acid, toluidine blue, and cephazolin $^{9}$ to detect netilmicin sensitive as well as resistant serratia strains. Rectal swabs, environmental swabs, and hand swabs from staff were pre-enriched overnight in $2.5 \mathrm{ml} 2.5 \%$ heart infusion broth and then subcultured on to the above media; handwashings from staff were also subcultured after overnight incubation and again at five days. All oxidase negative, Gram negative bacilli were checked for antibiotic sensitivity pattern and production of deoxyribonuclease and finally identified with the API $20 \mathrm{E}$ system.

Bacteriophage types and 0 serotypes were determined by the methods of Pitt et al. ${ }^{10}$

Antibiotic sensitivities were initially determined by a controlled disc method $^{11}$ on Sensitest agar (Oxoid) with $5 \%$ lysed horse blood, Escherichia coli NCTC 10418 being used as control. Minimum inhibitory concentrations of 10 antibiotics (see table II) were determined by doubling dilution in diagnostic sensitivity test agar (Oxoid) at $\mathrm{pH} 7 \cdot 3$. Isolates of $S$ marcescens were grown overnight in brainheart infusion broth (Difco) and broth cultures diluted to give a final inoculum on the plates of $10^{4}$ colony forming units. A multipoint inoculator (Denley) was used, delivering $1 \mu \mathrm{l}$ per inoculum, 25 to a plate. Plates were read after overnight incubation and the minimum inhibitory concentration taken as the lowest concentration of an antibiotic giving much reduced or no growth.

Aminoglycoside modifying enzymes were identified by determination of their substrate profile using the radioincorporation method described by Drasar. ${ }^{12}$

TABLE II-Minimum inhibitory concentrations $(m g / l)(n=228)$

\begin{tabular}{lllll}
\hline & \multicolumn{1}{c}{ Mode (range) } & & \multicolumn{1}{c}{ Mode (range) } \\
\cline { 1 - 1 } \cline { 5 - 6 } Tobramycin & $64(32->128)$ & & Cefotaxime & $0 \cdot 5(0 \cdot 12->32 \cdot 0)$ \\
Gentamicin & $1(0 \cdot 5-8 \cdot 0)$ & & Latamoxef & $0 \cdot 25(0 \cdot 12-32 \cdot 0)$ \\
Netilmicin & $64(64-512)$ & & Ceftazidime & $0 \cdot 12(0 \cdot 12-16 \cdot 0)$ \\
Amikacin & $16(8-128)$ & & Piperacillin & $2(1-128)$ \\
Cefuroxime & $64(16->256)$ & & Azlocillin & $16(8-128)$ \\
\hline
\end{tabular}

\section{Results}

The figure gives the results of the colonisation studies in 12 of the 13 babies from whom $S$ marcescens was isolated; in case 11 no colonisation studies were performed before death. Ten babies in the unit became colonised with the strain and two rectal isolations were made from babies in the temporary special care baby unit even after strict barrier nursing had been introduced. These babies were transferred to the closed unit but serratia was not isolated from them again. There was no spread within the unit to the "non-infected" area, and serratia was isolated neither from babies in other postnatal wards nor from new patients admitted to the unit after reopening. Rectal colonisation was the most frequent and persistent finding in all babies investigated, with urinary and perineal isolation next in frequency. Suprapubic aspirates were sterile in all but one case, indicating that urinary isolations often resulted from perineal contamination. Over $90 \%$ of rectal isolations were made from direct culture but pre-enrichment proved valuable for specimens from case 9 , in which colonisation was detected only intermittently. In cases 4 and 5 carriage from all sites disappeared after treatment with cefotaxime and gentamicin, but subsequently recurred perineally before rectal carriage was re-established. Of those babies from whom faecal specimens were obtained after discharge, most continued 
Week No of study
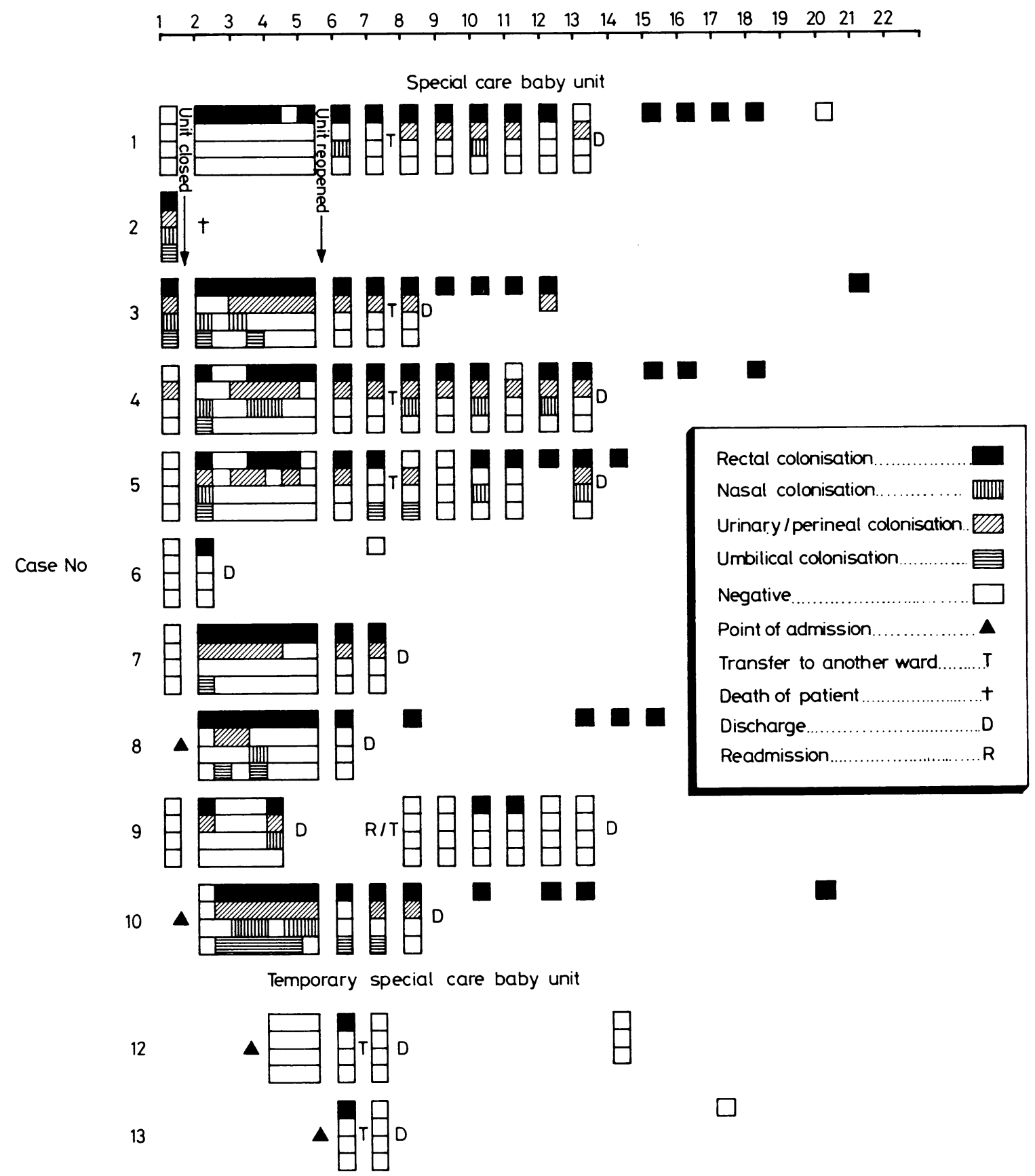

Temporal relation of colonisation at various sites with netilmicin resistant $S$ marcescens. In case 11 colonisation studies were not performed before death.

to be colonised for several weeks, and a positive isolate was obtained from one baby (case 3) 21 weeks after the first isolation and 12 weeks after discharge.

Netilmicin resistant $S$ marcescens was isolated from the hands of two members of staff. Hand swabs from a clinician taken after inadequate handwashing following examination of a colonised baby yielded the epidemic strain, as did handwashings from a nurse taken before handwashing after handling a colonised baby. Subsequent hand swabs, taken on one occasion from these subjects, were negative.

0 Serotyping and bacteriophage typing were performed on 194 isolates from clinical and screening specimens. All were serotype 0:14 and most were indistinguishable by phage typing, although minor differences in phage pattern were observed with the isolates from case 7.

A strain of $S$ marcescens was isolated from the sample introduction port and waste bottle of the blood gas analyser. This strain, however, differed from the epidemic strain by typing and was sensitive to netilmicin, tobramycin, amikacin, and gentamicin.

Disc sensitivity testing of 20 representative isolates showed resistance to ampicillin, cephradine, cefuroxime, amoxycillin/clavulanate, and nitrofurantoin. Trimethoprim and sulphonamide results varied from moderately sensitive to sensitive, and isolates were sensitive to chloramphenicol and nalidixic acid. Table II gives the results of quantitative sensitivity testing on 228 clinical and screening isolates. Mode minimum inhibitory concentrations indicate sensitivity to gentamicin, cefotaxime, latamoxef, ceftazidime, piperacillin, and azlocillin; moderate resistance to amikacin; and resistance to netilmicin, tobramycin, and cefuroxime. There was a wide range of minimum inhibitory concentrations for all antibiotics tested.

After the administration of gentamicin in case 1 an isolate of $S$ marcescens with increased resistance to all aminoglycosides and $\beta$-lactam agents was recovered from an endotracheal aspirate (table III). Isolates from three other babies who had received gentamicin 
and cefotaxime similarly exhibited increased resistance to aminoglycosides together with more pronounced resistance to $\beta$-lactams, especially cefotaxime-for example, case 8 (table III). Once established, these more resistant serratia were intermittently isolated.

TABLE III-Increasing resistance of serratia isolates after administration of gentamicin and gentamicin and cefotaxime. Figures are minimum inhibitory concentrations $(\mathrm{mg} / \mathrm{l})$

\begin{tabular}{|c|c|c|c|c|}
\hline & \multicolumn{2}{|c|}{ Case 1} & \multicolumn{2}{|c|}{ Case 8} \\
\hline & $\begin{array}{c}\text { Before } \\
\text { gentamicin }\end{array}$ & $\begin{array}{c}\text { After } \\
\text { gentamicin }\end{array}$ & $\begin{array}{l}\text { Before } \\
\text { gentamicin } \\
\text { + cefotaxime }\end{array}$ & $\begin{array}{c}\text { After } \\
\text { gentamicin } \\
\text { + cefotaxime }\end{array}$ \\
\hline $\begin{array}{l}\text { Netilmicin } \\
\text { Gentamicin } \\
\text { Tobramycin } \\
\text { Amikacin } \\
\text { Cefotaxime } \\
\text { Ceftazidime } \\
\text { Latamoxef } \\
\text { Cefuroxime } \\
\text { Piperacillin } \\
\text { Azlocillin }\end{array}$ & $\begin{array}{l}64 \\
1 \\
32 \\
16 \\
0 \cdot 5 \\
0 \cdot 12 \\
0 \cdot 25 \\
64 \\
2 \\
16\end{array}$ & $\begin{array}{r}512 \\
4 \\
>128 \\
64 \\
2 \\
1 \\
4 \\
>256 \\
8 \\
64\end{array}$ & $\begin{array}{l}64 \\
1 \\
64 \\
16 \\
0 \cdot 5 \\
0 \cdot 12 \\
0 \cdot 25 \\
64 \\
2 \\
16\end{array}$ & $\begin{array}{r}512 \\
4 \\
>128 \\
64 \\
32 \\
2 \\
16 \\
256 \\
32 \\
128\end{array}$ \\
\hline
\end{tabular}

Substrate profile studies showed that isolates produced the acetyltransferase $\mathrm{AAC}\left(6^{\prime}\right)$; this was confirmed by identification of reaction products by high pressure liquid chromatography (A M Lovering, personal communication).

\section{Discussion}

The pathogenic potential of $S$ marcescens in nurseries of newborn infants was recognised as early as 1966. Two outbreaks were described affecting a total of 21 babies, six of whom-all premature-died of septicaemia. ${ }^{15}$ The outbreak described here affected 13 babies, resulting in four cases of bacteraemia and two deaths. The second death (case 11) was unexpected because the infant, although moderately premature, was recovering well from mild respiratory distress syndrome yet died within 24 hours of a fulminant infection. The overall outcome might have been considerably worse had not the unit been closed at an early stage. Until then containment had proved difficult, and in fact spread to the temporary unit did occur even after closure.

Contaminated hands of personnel have been suggested as playing an important part in transmission of serratia in newborn infants, ${ }^{2}$ and adults, ${ }^{13}$ and isolation of the epidemic strain from hands of two members of staff suggests such a possibility in this outbreak. Spread to the temporary special care baby unit may have occurred via the hands of the few members of staff who moved between the units.

Although an environmental source such as scalp vein needles ${ }^{2}$ and saline in plastic bottles used for umbilical irrigation, ${ }^{5}$ has been found in some outbreaks, in others ${ }^{114}$ and the present episode no such source was found. In this epidemic there was a distinct lack of environmental contamination, and probably the most important reservoir within the unit was infected and colonised infants.

While in adults gastrointestinal carriage of $S$ marcescens is unusual, ${ }^{7} 1516$ in epidemics, especially in neonates, faeces have been implicated as an important reservoir for infections. ${ }^{2417}$ In this outbreak rectal colonisation was the most consistent finding, followed by isolation from urine and perineal swabs. Suprapubic aspirates performed on babies from whose urine serratia had been isolated showed that (except in one case) serratia was not in the bladder, and thus perineal or faecal contamination or both can be assumed.

Outbreaks of $S$ marcescens infection in south west England have been described, ${ }^{7}$ but the current strain was epidemiologically distinct from previous isolates in Bristol. It was sensitive to gentamicin and resistant to netilmicin, the resistance mechanism being the production of AAC $\left(6^{\prime}\right)$ enzyme. Sensitivity to gentamicin was retained because gentamicin $\mathrm{C}_{1}$, having a secondary amino group at the $6^{\prime}$ position, is not susceptible to acetylation by $\mathrm{AAC}\left(6^{\prime}\right) .{ }^{18}$ The production of $\mathrm{AAC}\left(6^{\prime}\right)$ by this strain has two important therapeutic implications. Firstly, since its introduction in Britain netilmicin has been marketed with emphasis on use in the newborn because of evidence for low toxicity. ${ }^{19}$ The possibility exists, however, that after extensive use of netilmicin in the unit selective pressure was exerted for this bacterial strain producing $\mathrm{AAC}\left(6^{\prime}\right)$. Eight of the 13 colonised or infected babies had previously received netilmicin and the index patient (case 1) had received four separate courses before the first isolation of $S$ marcescens. Although good in vitro activity of netilmicin against $S$ marcescens has been described, ${ }^{20}{ }^{21}$ it has been suggested that many serratia have low level $6^{\prime}$-acetylating activity, which may not be apparent on routine antimicrobial sensitivity testing. ${ }^{18}$ The other important point concerning $\mathrm{AAC}\left(6^{\prime}\right)$ is its conferment of resistance to amikacin, since this remains a most important reserve antibiotic for treatment of multiresistant bacterial infections. There is evidence that the AAC $\left(6^{\prime}\right)$ gene in $S$ marcescens is non-transferable and chromosomally located, ${ }^{22}$ and we are currently investigating this. Increasing resistance to amikacin developing during treatment of serratia infections has been described, ${ }^{73}$ and this is possibly due to induction of a chromosomal enzyme. Consistent with this is our finding of increased resistance to gentamicin, netilmicin, tobramycin, and amikacin after treatment with gentamicin. Similarly, induction of class 1 chromosomal $\beta$-lactamase might account for the emergence of increased resistance to cefotaxime, latamoxef, and ceftazidime. ${ }^{24}$ Latamoxef resistance developing during treatment of $S$ marcescens infections in patients with neoplastic disease has been documented. ${ }^{25}$ This illustrates the difficult therapeutic problem posed by $S$ marcescens.

We are grateful to Dr A Turner (microbiology department, Bristol Royal Infirmary), Mr M J Bywater, Mr H A Holt, and Mr A M Lovering (microbiology department, Southmead Hospital, Bristol) for invaluable technical work, and to Miss M Colbeck and all the nursing staff of the special care baby unit at Bristol Maternity Hospital for excellent support.

\section{References}

${ }^{1}$ Stenderup A, Faergeman O, Ingerslev M. Serratia marcescens infections in premature infants. Acta Pathol Microbiol Scand 1966;68:157-60.

2 Stamm WE, Kolff CA, Dones EM, et al. A nursery outbreak caused by Serratia marcescens-scalp-vein needles as a portal of entry. $\mathcal{F}$ Pediatr $1976 ; 89: 96-9$.

${ }^{3}$ Chakravarti A, Mandal A, Sharma KB. An outbreak due to multiple drug resistant Serratia marcescens in a children's hospital. Indian $\mathcal{f}$ Med Res $1981 ; 74: 196-201$.

4 Christensen GD, Korones SB, Reed L, Bulley R, McLaughlin B, Bisno AL. Epidemic Serratia marcescens in a neonatal intensive care unit importance of the gastrointestinal tract as a reservoir. Infect Control $1982 ; 3: 127-33$.

${ }^{5}$ McCormack RC, Kunin CM. Control of a single source nursery epidemic due to Serratia marcescens. Pediatrics $1966 ; 37: 750-5$

${ }^{6}$ Meyer RD, Lewis RP, Halter J, White M. Gentamicin-resistant Pseudomonas aeruginosa and Serratia marcescens in a general hospital. Lancet $1976 ;$ i :580-3.

'Bullock DW, Bidwell JL, Reeves DS, et al. Outbreaks of hospital infection in southwest England caused by gentamicin-resistant Serratia marcescens. Fournal of Hospital Infection 1982;3:263-73.

${ }^{8}$ Primavesi R, Lewis DA, Fleming PJ, Speller DCE. Serratia marcescens in a special baby unit. Lancet $1982 ;$ ii: 1164 .

${ }^{9}$ Farmer JJ, Silva F, Williams DR. Isolation of Serratia marcescens on deoxyribonuclease-toluidine blue-cephalothin agar. Applied Microbiology 1973;25:151-2.

${ }^{10}$ Pitt TL, Erdman YJ, Bucher C. The epidemiological type identification of Serratia marcescens from outbreaks of infection in hospitals. $\mathcal{F}$ Hyg 1980;84:269-83.

1 Stokes EJ, Waterworth PM. Antibiotic sensitivity tests by diffusion methods. Association of Clinical Pathologists' Broadsheet 1972 ; No 55.

12 Drasar FA. Detection of aminoglycoside degrading enzymes. In: Reeves DS, Phillips I, Williams JD, Wise R, eds. Laboratory methods in antimicrobial chemotherapy. Edinburgh: Churchill Livingstone, 1978 . $70-4$.

${ }^{13}$ Maki DG, Hennekens CG, Phillips CW, Shaw WV, Bennett JV. Nosocomial urinary tract infection with Serratia marcescens: an epidemiologic study. $\mathcal{J}$ Infect Dis 1973;128:579-87. 
14 Cardos SF, Florman AL, Simberkoff MS, Lanier L. Serratia marcescens : use of detailed characterisation of strains to evaluate an increase of isolates in an intensive care unit. Am $\mathcal{F}$ Med Sci 1973;266:477.

15 John JF Jr, McNeill WF. Characteristics of Serratia marcescens containing a plasmid coding for gentamicin-resistance in nosocomial infections. $\mathcal{f}$ Infect Dis $1981 ; 143: 810-7$.

16 Farmer JJ, Davis BR, Hickman FW, et al. Detection of Serratia outbreaks in hospital. Lancet 1976 ;ii:455-9.

17 Cook LN, Davis RS, Stover BH. Outbreak of amikacin-resistant Enterobacteriaceae in an intensive care nursery. Pediatrics $1980 ; 65: 264-8$.

${ }^{18}$ Miller GH, Sabatelli FJ, Hare RS, Waitz JA. Survey of aminoglycoside resistance patterns. Developments in Industrial Microbiology 1980;21: 91-104.

${ }^{19}$ Michalson $\mathrm{H}$, Halvorsen $\mathrm{K}$, Bergan T. Netilmicin in the treatment of neonates with moderate and severe infections. Scand $\mathcal{f}$ Infect Dis 1980;23,suppl:146-50.

${ }^{20}$ Langstaff $\mathrm{D}$, Schneler S, Righter J. Netilmicin: in vitro activity compared with that of other aminoglycosides against Serratia marcescens. f Antimicrob Chemother 1983;11:187-9.
21 Nolan CM, Fox PG. In vitro activity of netilmicin against recent clinical isolates of Serratia marcescens. Current Therapy and Research 1978; $23: 78-82$.

22 John JF Jr, McNeill WF, Price KE, Kresel PA. Evidence for a chromosomal site specifying amikacin resistance in multiresistant Serratia marcescens. Antimicrob Agents Chemother 1982;21:587-91.

${ }^{23}$ Craven PC, Jorgensen JH, Kaspar RL, Drutz DJ. Amikacin therapy of patients with multiply antibiotic-resistant Serratia marcescens infections: development of increasing resistance during therapy. $\mathrm{Am} \mathcal{F}$ Med 1977;62:902-10.

${ }^{24}$ Sanders CC. Novel resistance selected by the new expanded-spectrum cephalosporins: a concern. $\mathcal{F}$ Infect Dis 1983;147:585-9.

${ }^{25}$ Brown AE, Quesada O, Armstrong D. Moxalactam therapy of serious nosocomial serratia infections in patients with neoplastic disease. In: Periti P, Grassi GG, eds. Current chemotherapy and immunotherapy. Vol 1. Washington DC: American Society for Microbiology, 1982:299301.

(Accepted 14 fuly 1983)

\title{
The State of the Prisons
}

\section{Crisis upon crisis}

\author{
RICHARD SMITH
}

Crisis is a bankrupt word. We are surrounded by people shouting crisis, and we have become inured to the notion. Doctors work in a National Health Service that is said to be in crisis because of an economic crisis, and often they simply ignore the rhetoric and get on with their daily jobs. But in one part of British society, prisons, the word crisis, meaning a state in which a decisive change one way or the other is pending, may be used without hesitation or embarassment: our prisons will either have to be reformed or explode. Mr Leon Brittan's promise last week to provide 10600 new prison places by 1991 should help, but many will doubt that simply providing new places is enough.

The prison medical services are struggling hard at the moment to maintain a decent medical service within the crisis ridden prisons. But can you ever, as Lady Megan Bull, a former prison doctor and governer of Holloway, said to me, hope to practise good medicine in grossly overcrowded and run down prisons like Brixton, Wandsworth, or Strangeways? Quite possibly you cannot, and certainly the problems of the prison doctors are closely linked with the problems of the whole system. That is why, although this series is primarily concerned with prison health care, I am devoting one article to considering some of the broader problems.

\section{Overcrowding}

In the long term loss of direction and purpose might be the prison department's most important problem (26 November, p 1614), but overcrowding is the most acute problem. In England and Wales about 44000 prisoners are currently locked up in accommodation intended for 38500 , and the Home Office

British Medical Journal, London WC1H 9JR

RICHARD SMITH, MB, CHB, assistant editor estimates that the figures will rise to above 48000 before the end of the decade. Today the problem is so bad that some 500 remand prisoners are held in police cells because there is no room in the prisons. Conditions may be bad in local prisons, but they are worse in police cells, which are designed to keep prisoners only overnight, and the Home Secretary has promised that these men will be out of the police cells before Christmas. In Scotland and Northern Ireland overcrowding is not nearly such a pressing problem. Indeed, in Northern Ireland terrorist activity has declined, and the new prison that is being built in Maghaberry may prove superfluous if it continues to decline.

The problem of overcrowding has been called "serious" since 1946, when the prison population was $15800 .{ }^{1}$ By 1947 it was 17100 , and it has risen steadily ever since, apart from a minor hiccup when the prison officers took industrial action. The 1970s saw a wave of disorder and rioting in prisons, and prison governers wrote in a letter to the then Home Secretary, Merlyn Rees: "If the present trend continues there will be a serious loss of control" and "a probability of both staff and prisoners being killed."' Despite the May inquiry into the prisons, ${ }^{2}$ the trend has continued, and the last Home Secretary, William Whitelaw, described prison conditions as "an affront to a civilised society and a continued threat to law and order."3

\section{CAUSES OF OVERCROWDING}

Overcrowding has arisen obviously because of a mismatch between the number of prisoners and the capacity of the prisons. The number of prisoners might be assumed to have risen simply because the amount of crime has increased. But such an assumption cannot be made: nothing is simple in criminology, and the complexity of the links between the numbers of crimes committed, reported, recorded, and solved, and then the numbers of convictions, and the lengths of sentences makes the complexity of the problem of trying to unravel the factors that contribute to coronary artery disease look simple. As the Home Office Research and Planning Unit report The British Crime Survey puts it: "Variations over time or place in recorded 